IBAD Sosyal Bilimler Dergisi

IBAD Journal of Social Sciences

dergipark.org.tr/ibad

IBAD, 2021; (10): 354-369

DOI: $10.21733 /$ ibad. 845313

Özgün Araştırma / Original Article

\title{
Kadınlarda Sosyal Onay İhtiyacı, Kendini Sansürleme İsteği ve Depresyon Düzeyi Arasındaki İlişkilerin İncelenmesi
}

\section{The Examination of Relationships Between Need for Social Approval, Willingness to Self-Censor and Depression Levels in Women}

\author{
Müge Yukay-Yüksel ${ }^{1}$ \\ Şeniz Özgür-Şahin ${ }^{2 *}$ \\ Gözde Ekici ${ }^{3}$

\section{* Sorumlu yazar \\ Corresponding author}

${ }^{1}$ Doç. Dr., Marmara Üniversitesi, Türkiye

Assoc. Prof. Dr., Marmara University, Turkey

muge.yuksel@marmara.edu.tr

ORCID ID 0000-0002-7425-2716

${ }^{2}$ Yüksek Lisans Öğrencisi, Marmara Üniversitesi, Türkiye

MA Student, Marmara University, Turkey

cagdas.seniz@gmail.com

ORCID ID 0000-0002-1695-4293

3Yüksek Lisans Öğrencisi, Marmara Üniversitesi, Türkiye

MA Student, Marmara University, Turkey

gzdee96@gmail.com

ORCID ID 0000-0001-6183-0356

Makale geliş tarihi / First received : 22.12.2020

Makale kabul tarihi / Accepted : 01.04.2021

\section{Bilgilendirme / Acknowledgement:}

1- Araştırmacıların katkı oranları eşittir.

2- Bu makale 9. Uluslararası Yükseköğretimde Psikolojik Danışmanlık ve Rehberlik Kongresi'nde sözlü bildiri olarak sunulmuştur.

3- Çalışma grubunda yer alan tüm kadınlara teşekkür ederiz.

4- Makalenin yazarları arasında çıkar çatışması bulunmamaktadır.

5- Veri toplama süreci 2019 yılı içerisinde gerçekleştirilmiştir.

6- Araştırmada kullanılan ölçeklerin kullanım izinleri ilgili araştırmacılardan e-posta yoluyla alınmıştır.

7- Katılımcılara Aydınlatılmış Onam Formu sunulmuş ve gönüllü olarak araştırmaya katılım göstermeleri sağlanmıştır.

8- Bu makalede araştırma ve yayın etiğine uyulmuştur.

This article was checked by iThenticate. Similarity Index 14\%

\section{Atıf bilgisi / Citation:}

Yukay-Yüksel, M., Özgür-Şahin, Ş., Ekici, G. (2021). Kadınlarda sosyal onay ihtiyacı, kendini sansürleme isteği ve depresyon düzeyi arasındaki ilişkilerin incelenmesi. IBAD Sosyal Bilimler Dergisi, (10), 354-369. 
ÖZ

$\mathrm{Bu}$ araştırmanın temel amacı, kadınların sosyal onay ihtiyaçları, kendini sansürleme istekleri ve depresyon düzeyleri arasındaki ilişkinin incelenmesidir. Araştırmanın çalışma grubunu 35 yaş ve üzeri 285 kadın oluşturmaktadır. Araştırmada veri toplamak amacıyla; Sosyal Onay İhtiyacı Ölçeği, Kendini Sansürleme İsteği Ölçeği ve Beck Depresyon Envanteri kullanılmıştır. Verilerin analizinde Spearman Korelasyon Analizi, Kruskal Wallis H Testi, Bağımsız Gruplar t Testi ve Mann Whitney U Testi kullanılmıştır. Bulgular incelendiğinde, sosyal onay ihtiyacı ile kendini sansürleme isteği ve sosyal onay ihtiyacı ile depresyon düzeyi arasında pozitif yönde orta düzeyde manidar bir ilişkinin olduğu görülmüştür. Kendini sansürleme isteği ile depresyon düzeyi arasında ise pozitif yönde düşük düzeyde manidar bir ilişki bulunmuştur. Bağımsız değişkenlerin (eğitim durumu, çalışma durumu, sosyal güvence, medeni durum, aile tipi) etkisini incelemek adına yapılan fark testleri sonuçlarına göre sosyal onay ihtiyacı aile tipine göre manidar bir farklılık göstermiştir. Kendini sansürleme isteğinin eğitim durumuna, çalışma durumuna ve medeni duruma göre manidar bir şekilde farklılaştığ bulunmuştur. Depresyon düzeyinin ise çalışma durumuna göre manidar bir şekilde farklılaştığı görülmüştür.

\section{Anahtar kelimeler}

Kadın, Sosyal Onay İhtiyacı, Kendini Sansürleme İsteği, Depresyon

\section{ABSTRACT}

The main purpose of this study is to examine the relationship between women's social approval needs, selfcensorship, and depression levels. The study group of the research consists of 285 women aged 35 and over. In order to collect data in the research; Need For Social Approval Scale, The Willingness to Self-Censor Scale and Beck Depression Inventory were used. Spearman Correlation Analysis, Kruskal Wallis H Test, Independent Groups t Test and Mann Whitney U Test were used to analyze the data. When the findings are examined, it is seen that there is a moderately significant positive correlation between the need for social approval and the self-censorship and the need for social approval and the level of depression. On the other hand, a low level and positive relationship was found between the self-censorship and the level of depression. According to the results of the difference tests conducted in order to examine the effect of independent variables (educational status, employment status, social security, marital status, family type), the need for social approval varies significantly according to family type. The self-censorship showed a significant difference according to education, employment and marital status. Depression level was found to differ significantly according to working status.

\section{Keywords}

Women, Need for Social Approval, Willingness to Self-Censor, Depression 


\section{GíRiş}

Bireyin çevresindeki kişilere, olaylara ve nesnelere duyduğu ilgi doğumla birlikte getirdiği bir durumdur ve sosyal ortamlarda kendisini göstermektedir. Bu ilginin beraberinde gelişen yakın ilişkiler kurma ve ilişkilerinde istendik biri olma arzusu, yaşam boyu gerçekleştirilmek istenen en önemli durumlardan biri olarak değerlendirilmektedir (Erözkan, 2005). Kurulan ilişkiler içerisinde alınan geri bildirimler ise kişinin sosyal çevresi tarafından nasıl algılandığı ve istendik biri olup olmadığı değerlendirmelerinde etkili bir rol oynamaktadır. Yapılan araştırmalara göre kişiler olumlu bir öz imajı destekleyen geri bildirimler almayı daha çok tercih etmektedirler (Akt. Leary, 2007). Bu tercih ise kişinin kendi düşünceleri yerine diğerlerinin ilgilerini, tercihlerini ve beklentilerini bir değerlendirme süzgecinden geçirerek, olumlu izlenimler yaratabilecek karşılıklar vermesine yol açmaktadır (Barreto ve Ellemers, 2000; Gino, Sezer ve Huang, 2020). İzlenim yönetimi olarak adlandırılan bu değerlendirme aşaması (Leary ve Kowalski, 1990) bir açıdan insanların sosyal onay almak adına diğgerlerinde oluşabilecek izlenimleri yönlendirmekle sürekli olarak ilgilendikleri anlamına gelmektedir (Akt. Eberhard, Matthes ve Ulrich, 2015).

Kişiler kendi kimliklerini güçlendirmek adına sosyal onaylara ihtiyaç duymaktadırlar (Eberhard, Matthes ve Ulrich, 2015). Sosyal onay ihtiyacı, çevredeki kişilerin beklentileri olarak değerlendirilen kıstasların önemli görülmesi ve bu kişilerin çeşitli durumlar karşısında getirdikleri yargılara önem verilmesi ile alakalı bir kavramdır (Karaşar ve Öğülmüş, 2016). Bulunulan ortamlarda arzu edilen karşılıklar sunmak ve beğeni kazanacağı düşünülen davranışlarda bulunmak gibi onaylanmamayı engellemek üzere kişinin kendisini şekillendirme tavırları bu ihtiyacın göstergeleri olarak değerlendirilmektedir (Leite ve Beretvas, 2005; McCollum, 2009).

Kişilerarası etkileşimde önemli bir yere sahip olan sosyal onay ihtiyacı sosyal bağların kurulmasıyla yakınlaşmayı sağlarken aynı zamanda bireyin kendisinden çok diğerlerinin beklentilerine göre bir tutum sergilemesine neden olmaktadır (Karaşar ve Öğülmüş, 2016). Bu ihtiyacın davranışlarımıza ilişkin etkilerini inceleyen çalışmalara bakıldığında; sosyal onayın verilecek tepki üzerinde gecikmeye neden olduğu (Jones ve Tager, 1972), sosyal onay ihtiyac1 yüksek olan kişilerin bu ihtiyacı düşük olanlara kıyasla davranışlarını daha sık değiştirdikleri (Buckhout, 1965) ve sosyal onay ihtiyacının verilen yanitlar üzerinde cezalandırılmanın etkisinden daha kuvvetli olduğu (Crowne ve Strickland, 1961) sonuçlarının yer aldığı görülmektedir. Aynı zamanda çeşitli çalışmalar bu ihtiyacın; erkeklere kıyasla kadınlarda daha yüksek düzeyde olduğunu (Ambler ve Elkins, 1986; Akt. Dinç-Yurtal, 1999; Danilchenko, 2018) ve toplumun kültürel yapısından etkilendiğini ortaya koymuştur (Karaşar ve Öğülmüş, 2016; Twenge ve Im, 2007).

Türk toplumunda kişilerin kendilerini diğerleriyle olan ilişkilerine göre tanımladıkları, "Elalem ne der?" “Onun kulağına gitmesin" vb. ifadelerin bir uzantısı olarak (Karaşar ve Ögülmüş, 2016) kimi zaman duyguların gizlendiği ve açık iletişimin kurulamadığı görülmektedir (Şahan ve Akbaş, 2018). Kayahan ve arkadaşları (2003)'na göre küçük yaşlardan itibaren erkeklerden daha değersiz olduğunu öğrenip, düşük düzeyde bir benlik kavramı edinen kadınlar bu konuda daha çok baskı altındadırlar. Bu yönüyle kültürel yapımızda birçok konunun kadınlar tarafından konuşulması dahi tabulaştırılmakta ve kadınların sosyal hayatta ataerkil zihniyete boyun eğmeleri beklenmektedir (Komut, 2011). Kadınlara dönük idealize edilmiş kültürel reçetelerin içselleştirilmesi ise kurdukları ilişkilerde kendilerini 
otantik bir şekilde ifade edememelerine (Hurst, 2010) diğer bir ifadeyle kendilerini sansürlemelerine neden olmaktadır.

Kendini sansürleme kavramı; kişiye ait gerçek görüşün, bu görüşü onaylamayacağı algılanan diğerleriyle paylaşılmaması olarak tanımlanmaktadır (Hayes, Glynn ve Shanahan, 2005). Bu kavram onaylanmamaktan kaçınmak adına (Chan, 2018; Hayes, Uldall ve Glynn, 2010), düşünce aktarımlarının bilinçli olarak engellemesi şeklinde de açıklanabilir (Das ve Kramer, 2013). Bu kavramla bağlantılı olarak Jack (1991, 1999) kadınlardaki depresif belirtileri incelemek adına "Kendini Susturma (Self-Silencing)" teorisini geliştirmiştir. Bu model toplumsal cinsiyet eşitsizliğinin ve cinsiyete ilişkin sosyal beklentilerin kadınlarda belirli bilişsel şemalara yol açabileceğini önermiştir. Bu şemaların ise öfkeyi bastırarak, kendine yönelik bir şeyler yapmayı engelleyerek ve kendini ifade etmeyi sansürleyerek kadınlar üzerinde depresyona yönelik bir kırılganlık yaratabileceği belirtilmiştir (Akt. Grant ve arkadaşları, 2009). Yapılan araştırmalara bakıldığında da kendini susturmanın çeşitli kadın popülasyonları üzerinde depresif semptomlarla anlamlı bir şekilde ilişkili olduğu sonuçlarına ulaşıldığ1 görülmektedir (Jack ve Dill, 1992; Duarte ve Thompson, 1999; Ali, Oatley ve Toner, 2002; Ali ve Toner, 2001).

Depresyonla ilişkili önemli değişkenlerden bir diğeri sosyal onay ihtiyacıdır. Beck ve arkadaşları (1979) diğerleri tarafından onaylanma ihtiyacı olduğuna inanan kişilerin bu onaya sahip oldukları zaman daha iyi hissettiklerine değinmiştir (Akt. Canlı ve Karaşar, 2021). Dolayısıyla bu inanışa sahip olan kişiler, kendilerine değer atfetmek adına çevresindekilerin onayına bağlı kalacak şekilde işlevsel olmayan tutumlar sergileyebilmekte (Dobson ve Dozois, 2008) ve bu tutumlar depresyon süreçlerinin yaşanmasına neden olabilmektedir. Benzer şekilde Bebek (2012) onay bağımlılığının sosyal anksiyete bozukluğu ve depresyon gibi birçok bozukluğa temel hazırlamakta olduğunu belirtmektedir. Yapılan araştırmalara bakıldığında da bu iki kavram arasında pozitif yönlü anlamlı ilişkilerin elde edildiği dikkat çekmektedir (Quinlan, Pilkonis ve Shea, 1995; Erözkan, 2005).

Depresif belirtiler yönünden kadın cinsiyetini risk faktörü olarak niteleyen çalışmalar incelendiğinde; kadınların kişilerarası etkileşimlerden ve sosyo-demografik faktörlerden kaynaklı daha yüksek düzeyde depresyon bildirdikleri görülürken, erkeklerin bu etkenlerden bağımsız olarak depresif belirtiler gösterdikleri dikkat çekmektedir (Kendler, Thornton ve Prescott, 2001; Barnow vd., 2002). Bu açıdan sağlıklı ilişkiler kurmanın ve sosyalleşmenin, kadınların kendilerini sansürleme ihtiyacını ve bunlardan kaynaklı depresyonlarını azaltacağı düşünülebilir. Ayrıca sosyal onay ihtiyacının da bu iki değişkeni etkileyeceği varsayılarak bu araştırmanın temel problemini sosyal onay ihtiyacı, kendini sansürleme isteği ve depresyon arasındaki ilişkinin incelenmesi oluşturmaktadır. Konu ile ilgili literatür incelendiğinde; eğitim düzeyinin artmasıyla birlikte sosyal onay ihtiyacında azalmaların görülmesi veya çalışan kadınlara kıyasla çalışmayan kadınların depresyon düzeylerinin daha yüksek olduğunun saptanması gibi çeşitli sosyo-demografik değişkenlerin de sosyal onay ihtiyacı, kendini sansürleme isteği ve depresyon düzeyi üzerinde bir arada ya da ayrı ayrı etkili olduğu gözlenmiştir (Cengiz-Özyurt ve Deveci, 2010; Değirmenci, 2019; Etiler, 2015; Önen, Kaya, 2019; Kaptanoğlu ve Seber, 1995; Okyay ve arkadaşları, 2011; Pehlivan, 2017). Bu nedenle araştırmada ele alınan değiş̧enlerin, çalışma grubunda yer alan kadınların eğitim düzeyleri, çalışma durumları, medeni halleri, sosyal güvenceye sahip olup olmamaları ve içerisinde bulundukları aile tipi gibi değişkenlere göre farklılaşabileceği beklenmektedir. Elde edilen 
bulguların kadın çalışmaları literatürüne katkı sağlayacağı ve bu alanda çalışan gerek araştırmacılara gerek uygulayıcılara farklı bir bakış açısı kazandırabileceği ifade edilebilir.

\section{YÖNTEM}

\section{Araştırma Modeli}

35 yaş ve üzerindeki kadınlar üzerinde sosyal onay ihtiyacı, kendini sansürleme isteği ve depresyon düzeylerinin birbirleriyle olan ilişki durumlarının incelenmesi ile bağımsız değişkenler açısından bu araştırma değişkenlerinin farklılaşma durumlarının ortaya konulması amaçlarıyla bu çalışma ilişkisel tarama modeline ve nedensel karşılaştırma modeline dayalı olarak gerçekleştirilmiştir.

\section{Çalışma Grubu}

$\mathrm{Bu}$ araştırmanın çalışma grubunu İstanbul İlinde yaşayan 285 kadın oluşturmaktadır. Katılımcılara kolay ulaşılabilir örneklem belirleme yöntemi kullanılarak ulaşılmıştır (Yıldırım ve Şimşek, 2018; Baltacı, 2018). Katılımcıların; yaş aralığı 35 ile 60 arasında değişmekte olup, yaş ortalamaları $44(\mathrm{ss}=8)$ 'tür.

Katılımcılardan 216'sı (\%75,8) evli, 32'si (\%11,2) bekâr, 26'sı (\%9,1) boşanmış ve 11'inin $(\% 3,9)$ de eşi vefat etmiştir. Eğitim durumu açısından çalışma grubunun dağılımına bakıldığında çalışmada; okula gitmeyen 15 (\%5,3), ilkokul mezunu 79 (\%27,7), lise mezunu $93(\% 32,6)$ ve üniversite mezunu 98 (\%34,4) kadın katılımcı olduğu görülmektedir. Bu kadınlar içerisinde herhangi bir işte çalışan 132 (\%46,3), çalışmayan $153(\% 53,7)$ kadın bulunurken, sosyal güvencesi olan $226(\% 79,3)$ ve olmayan 59 (\%20,7) kadın bulunmaktadır. Aile tipine göre dağılıma bakıldığında ise çekirdek aile içerisinde yaşayan $264(\% 92,6)$ ve geniş aile içerisinde yaşayan $21(\% 7,4)$ kadın katılımcı yer almaktadır.

\section{Veri Toplama Araçları}

Sosyal Onay İhtiyacı Ölçeği (SOIO). Karaşar ve Öğülmüş (2016) tarafından yetişkinlerin sosyal onay ihtiyacı düzeylerini belirlemek amacıyla geliştirilen bu ölçek, 25 maddeden oluşan beşli likert tipi bir ölçektir. Ölçekte ters madde bulunmamaktadır. Ölçekten alınan puanların artması sosyal onay ihtiyacının da arttığını göstermektedir. Ölçeğin geçerlik analizleri kapsamındaki açımlayıcı faktör analizi sonuçlarına göre ölçekte yer alan 3 alt boyut toplam varyansın \%45'ini açıklamaktadır. Doğrulayıcı faktör analizi sonuçları da ölçeğin üç alt boyuttan oluştuğunu göstermektedir. Bu üç alt boyutun iç tutarlılık katsayıları başkalarının yargılarına duyarlılık için .83 , sosyal geri çekilme için .80 ve olumlu izlenim bırakma için .80 olarak hesaplanmıştır. Test-tekrar test güvenirlik katsayısı ise .90 olarak bildirilmiştir (Karaşar ve Öğülmüş, 2016).

Kendini Sansürleme İsteği Ölçeği (KSïÖ). Türkçeye uyarlaması Coşkun, Durak ve Elgin (2012) tarafından gerçekleştirilen KSİÖ, yetişkinlerin kendilerini sansürleme isteğine yönelik düzeylerini belirlemek amacıyla geliştirilmiştir. KSİÖ, 8 maddeden oluşan beşli likert tipi bir ölçektir. Ölçeğin 4. ve 8. maddesi ters madde şeklinde puanlanmaktadır. Uyarlama çalışmaları kapsamında gerçekleştirilen doğrulayıc faktör analizi sonucuna göre ölçeği oluşturan 8 maddenin, orijinal ölçekle tutarlı olacak şekilde tek bir faktörde toplandığı ve açımlayıcı faktör analizi sonuçlarına göre ise açıklanan toplam varyans değerinin $\% 44.99$ olduğu görülmüştür. 
Güvenirlik çalışmaları kapsamında ölçeğin Cronbach Alfa değeri .82 ve test-tekrar test güvenirlik katsayısı ise .75 olarak bulunmuştur (Coşkun, Durak ve Elgin, 2012).

Beck Depresyon Envanteri (BDE). Türkçeye uyarlaması Hisli (1989) tarafından gerçekleştirilen BDE ile depresyon belirtilerinin derecesinin, sayılarla ifade edilebilmesi amaçlanmaktadır. 21 maddeden oluşan bu ölçekte katılımcılar maddeleri 0-1-2-3 rakamları üzerinden puanlamaktadır. Alınabilecek toplam puan aralığı 0 ile 63 arasında olan bu ölçekte alınan puanın artması depresyon düzeyinin arttığına işaret etmektedir (Akt. Eryılmaz, Pekuslu ve Kayacı, 2007). Geçerlik çalışmaları kapsamında gerçekleştirilen faktör analizi sonuçları ölçeğin; umutsuzluk, kişinin kendine yönelik olumsuz duyguları, bedensel kaygılar ve suçluluk duygulanımları olmak üzere toplam 4 alt boyuttan oluştuğunu göstermiştir. Güvenirlik çalışmaları kapsamında yarıya bölme tekniği sonucu korelasyon düzeyi .74 olarak bildirilmiştir. Ölçeğin Cronbach Alfa güvenirlik katsayısı ise .80 olarak bulunmuştur (Hisli, 1989).

\section{İsslem ve İstatistiksel Analiz}

Ölçeklerin kullanım izinlerinin alınmasının ardından bu ölçekler gönüllü olan katılımcılara 25 Mart - 5 Mayıs 2019 tarihleri arasında ulaştırılmıştır. Katılımcıların 193'üne yüz yüze ve 92'sine Google Formlar aracılığıyla ulaştırılan ölçeklerden elde edilen veriler SPSS 18.0 paket programiyla analiz edilmiştir.

Araştırma değişkenlerinin birbirleriyle olan ilişkileri, normal dağılım göstermemeleri nedeniyle Spearman Korelasyon Analizi kullanılarak incelenmiştir. Araştırma değişkenlerinin bağımsız değişkenler açısından farklılaşma durumlarının incelenmesi amacıyla analiz gereklilikleri göz önünde bulundurularak; Kruskal Wallis H Testi, Bağımsız Gruplar t Testi ve Mann Whitney U Testi uygulanmıştır.

\section{BULGULAR}

Araştırmada ele alınan sosyal onay ihtiyacı, kendini sansürleme isteği ve depresyon değişkenleri arasındaki ilişkiler incelendiğinde tüm değişkenlerin $p<.01$ anlamlılık düzeyinde ilişkili oldukları dikkat çekmektedir. Araştırmanın temel değişkenlerine ilişkin betimsel değerler ve korelasyon değerleri aşağıda sunulmaktadır:

Tablo 1. Betimsel İstatistiki Değerler ve Değişkenler Arasındaki İlişkiler

\begin{tabular}{lrrrccc}
\hline Değişken & $n$ & $M$ & $S S$ & 1 & 2 & 3 \\
\hline $\begin{array}{l}\text { 1. Sosyal Onay } \\
\text { İhtiyacı }\end{array}$ & 285 & 68.27 & 18.05 &. & \\
$\begin{array}{l}\text { 2. Kendini Sansürleme } \\
\text { İsteği }\end{array}$ & 285 & 11.94 & 6.28 & $.45^{* *}$ &. \\
\begin{tabular}{l} 
3. Depresyon \\
\hline
\end{tabular} & 285 & 9.66 & 7.19 & $.35^{* *}$ & $.22^{* *}$ &. \\
\hline
\end{tabular}
${ }^{*} p<.05,{ }^{* *} p<.01$

Tablo 1'de yer alan Spearman Korelasyon Analizi sonuçlarına göre sosyal onay ihtiyacı ile kendini sansürleme isteği arasında $(\mathrm{r}=.45 ; p=.00)$ ve sosyal onay ihtiyacı ile depresyon düzeyi arasında $(\mathrm{r}=.35 ; p=.00)$ orta düzeyde pozitif yönde manidar bir ilişki bulunmaktadır. Kendini 
sansürleme isteği ile depresyon düzeyi arasında ise düşük düzeyde pozitif yönde manidar bir ilişkinin olduğu görülmektedir $(\mathrm{r}=.22 ; p=.00)$.

Tablo 2. Araştırma Değişkenlerinin Bağımsız Değişkenlere Göre Farklılaşmalarına İlişkin Analiz Sonuçları

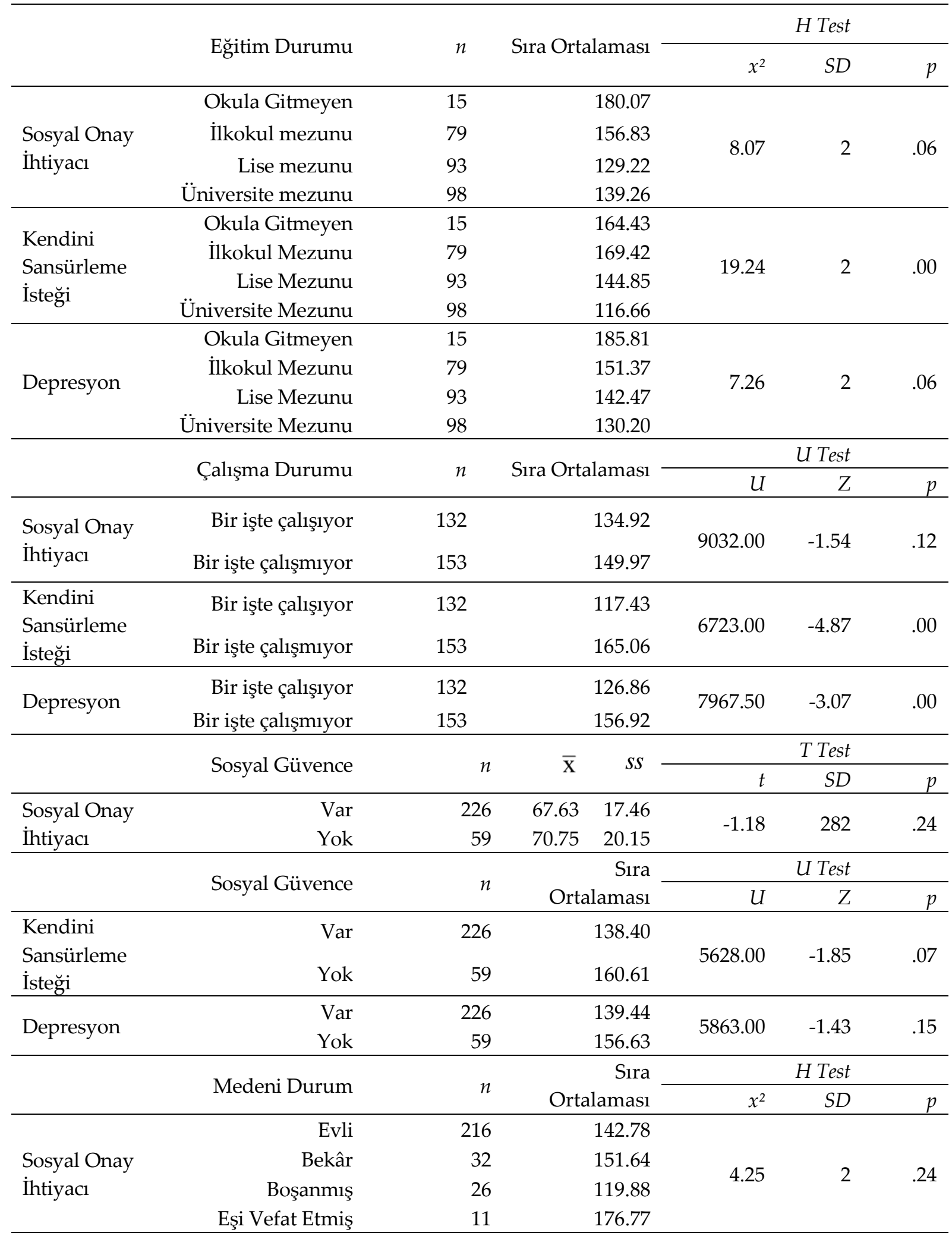




\begin{tabular}{|c|c|c|c|c|c|c|}
\hline \multirow{4}{*}{$\begin{array}{l}\text { Kendini } \\
\text { Sansürleme } \\
\text { İsteği }\end{array}$} & Evli & 216 & 146.90 & \multirow{4}{*}{8.84} & \multirow{4}{*}{2} & \multirow{4}{*}{.03} \\
\hline & Bekâr & 32 & 118.42 & & & \\
\hline & Boşanmış & 26 & 120.85 & & & \\
\hline & Eşi Vefat Etmiş & 11 & 190.23 & & & \\
\hline \multirow{6}{*}{ Depresyon } & Evli & 216 & 140.48 & \multirow{4}{*}{4.66} & \multirow{4}{*}{2} & \multirow{4}{*}{.20} \\
\hline & Bekâr & 32 & 130.13 & & & \\
\hline & Boşanmış & 26 & 170.04 & & & \\
\hline & Eşi Vefat Etmiş & 11 & 166.09 & & & \\
\hline & \multirow{2}{*}{ Aile Tipi } & \multirow{2}{*}{$n$} & \multirow{2}{*}{$\overline{\mathrm{X}}$} & \multicolumn{3}{|c|}{ T Test } \\
\hline & & & & $t$ & $S D$ & $p$ \\
\hline \multirow{4}{*}{$\begin{array}{l}\text { Sosyal Onay } \\
\text { İhtiyacı }\end{array}$} & Çekirdek Aile & 264 & 67.60 & \multirow{2}{*}{-2.25} & \multirow{2}{*}{282} & \multirow{2}{*}{.03} \\
\hline & Geniş Aile & 21 & 76.76 & & & \\
\hline & \multirow{2}{*}{ Aile Tipi } & \multirow{2}{*}{$n$} & \multirow{2}{*}{$\begin{array}{r}\text { Sira } \\
\text { Ortalaması }\end{array}$} & \multicolumn{3}{|c|}{$U$ Test } \\
\hline & & & & $U$ & Z & $p$ \\
\hline \multirow{2}{*}{$\begin{array}{l}\text { Kendini } \\
\text { Sansürleme } \\
\text { İsteği }\end{array}$} & Çekirdek Aile & 264 & 143.90 & \multirow[b]{2}{*}{2534.50} & \multirow[b]{2}{*}{-.65} & \multirow[b]{2}{*}{.51} \\
\hline & Geniş Aile & 21 & 131.69 & & & \\
\hline \multirow{2}{*}{ Depresyon } & Çekirdek Aile & 264 & 143.05 & \multirow{2}{*}{2759.00} & \multirow{2}{*}{-.04} & \multirow{2}{*}{.97} \\
\hline & Geniş Aile & 21 & 142.38 & & & \\
\hline
\end{tabular}

ANOVA varsayımları dikkate alındığında eğitim durumuna göre; kendini sansürleme isteği ve depresyon değişkenlerinin normal dağılım göstermediği, sosyal onay ihtiyacının ise varyansların homojenliği varsayımını sağlamadığı $(\mathrm{F}=3.32 ; p=.02)$ görülmüştür. Dolayısıyla bu analizde ANOVA yerine non-parametrik karşılığı olan Kruskal Wallis H Testi uygulanmıştır. Tablo 2'de yer alan H Testi sonucuna göre çalışma grubunu oluşturan kadınların sosyal onay ihtiyac1 $\left[\chi^{2}(2)=8.07 ; p=.06\right]$ ve depresyon $\left[\chi^{2}(2)=7.26 ; p=.06\right]$ düzeyleri eğitim durumuna göre farklılık göstermezken, kendini sansürleme isteği eğitim durumuna göre manidar bir farklılık göstermiştir $\left[\chi^{2}(2)=19.24 ; p=.00\right]$.

Kendini sansürleme isteğinin eğitim durumuna ilişkin farklılaşmasının hangi gruplardan kaynaklandığını belirlemek üzere Benferroni düzeltmeli Mann Whitney U Testi uygulanmış ve bu kapsamda $p$ değerinin maksimum kabul edilebilir düzeyi 0.01 olarak belirlenmiştir $(0.05 / 6=0.01)$. Nihai analiz sonucuna bakıldığında, kendini sansürleme isteğinin ilkokul mezunu- üniversite mezunu [U=2458.50; $Z=-4.17 ; p=.00]$ grupları arasında manidar bir şekilde farklılaştığı görülmüştür. Bu sonuca göre ilkokul mezunu olan kadınların (Sıra Ortalama Puanı= 106.88), üniversite mezunu olan kadınlara (Sıra Ortalama Puanı= 74.59) kıyasla kendilerini daha çok sansürledikleri söylenebilir. Diğer gruplara uygulanan fark testi sonuçlarında ise manidar bir farklılık bulunmamıştır.

Araştırma değişkenlerinin çalışma durumuna göre normal dağılım göstermemeleri sebebiyle fark analizinde Bağımsız Değişkenler $t$ Testi yerine non-parametrik karşılı̆̆ı olan Mann Whitney U Testi uygulanmıştır. Tablo 2'de yer alan bulgulara bakıldığında, araştırma grubunu oluşturan kadınların sosyal onay ihtiyacı düzeyleri çalışma durumuna göre manidar bir farklılık göstermezken [U=9032.00; $Z=-1.54 ; p=.12]$, kendini sansürleme isteği $[\mathrm{U}=6723.00 ; Z=$ $4.87 p=.00]$ ve depresyon [ $\mathrm{U}=7967.50 ; Z=-3.07 ; p=.00]$ düzeyleri çalışma durumuna göre manidar bir farklılık göstermiştir. Bu analiz sonuçlarına göre herhangi bir işte çalışmayan kadınların çalışan kadınlara kıyasla kendilerini sansürlemeye daha çok eğilim gösterdikleri ve daha depresif hissettikleri söylenebilir. 
Sosyal onay ihtiyacının, sosyal güvence kategorilerine göre normal dağılım göstermesi ve varyansların homojenliğini sağlaması neticesinde fark analizinde Bağımsız Gruplar $\mathrm{t}$ Testi uygulanmıştır. Kendini sansürleme isteği ve depresyon değişkenleri ise sosyal güvence kategorilerine göre normal dağılım göstermemiştir. Bu sebeple bu değişkenlerin fark analizinde Mann Whitney U Testi uygulanmıştır. Tablo 2'de yer alan analiz sonuçlarına bakıldığında, çalışma grubunu oluşturan kadınların; sosyal onay ihtiyacı [ $\mathrm{t}_{(282)}=-1.18 ; p=.24$, kendini sansürleme isteği $[\mathrm{U}=5628.00 ; \mathrm{Z}=-1.85 ; p=.07]$ ve depresyon $[\mathrm{U}=5863.00 ; \mathrm{Z}=-1.43 ; p=$ .15] düzeylerinin sosyal güvenceye sahip olup olmama durumlarına göre manidar bir farklılık göstermediği görülmektedir.

Araştırma değişkenlerinin medeni durum kategorilerine (bekâr, evli, boşanmış, eşi vefat etmiş) göre normal dağılım göstermemeleri neticesinde fark analizinde Kruskal-Wallis H Testi kullanılmıştır. Tablo 2'de yer alan H Testi sonucuna göre çalışma grubunu oluşturan kadınların; sosyal onay ihtiyacı $\left[\chi^{2}(2)=4.25 ; p=.24\right]$ ve depresyon $\left[\chi^{2}(2)=4.66 ; p=.20\right]$ düzeyleri medeni duruma göre manidar bir farklılık göstermezken, kendini sansürleme isteği medeni duruma göre manidar bir farklılık göstermiştir $\left[\chi^{2}(2)=8.84 ; p=.03\right]$.

Kendini sansürleme isteğinin medeni durum içerisindeki hangi gruplar arasında farklılaştığını belirlemek üzere Benferroni düzeltmeli Mann Whitney U Testi uygulanmıştır. Bu kapsamda $p$ değerinin maksimum kabul edilebilir düzeyi 0.01 olarak belirlenmiştir. Analiz sonuçlarına bakıldığında, kendini sansürleme isteğinin bekâr- eşi vefat etmiş grupları arasında manidar bir şekilde farklılaştığı görülmüştür [U= 80.500; $Z=-2.67 ; p=.00]$. Bu analiz sonucuna göre eşi vefat eden kadınların (Sıra Ortalama Puanı= 30.68) bekâr kadınlara (Sıra Ortalama Puanı= 19.02) göre kendilerini sansürlemeye daha çok eğilim gösterdikleri söylenebilir. Medeni durum içerisindeki diğer gruplara uygulanan Mann Whitney U Testi sonuçlarında ise manidar bir farklılık bulunmamıştır.

Sosyal onay ihtiyacının aile tipi kategorilerine göre normal dağılım göstermesi ve varyansların homojenliğini sağlaması neticesinde fark analizinde Bağımsız Gruplar t Testi uygulanmıştır. Kendini sansürleme isteği ve depresyon düzeyi ise aile tipi kategorilerine göre normal dağılım göstermemiştir. $\mathrm{Bu}$ sebeple bu değişkenlerin fark analizinde Mann Whitney U Testi uygulanmıştır. Tablo 2' de yer alan analiz sonuçlarına bakıldığında, çalışma grubunu oluşturan kadınların; kendini sansürleme isteği $[\mathrm{U}=2534.50 ; \mathrm{Z}=-.65 ; p=.51]$ ve depresyon $[\mathrm{U}=2759.00 ; \mathrm{Z}=$ -.04; $p=.97]$ düzeyleri aile tipine göre manidar bir farklılık göstermezken, sosyal onay ihtiyacı düzeyinin aile tipine göre manidar bir farklılık gösterdiği görülmektedir $\left[\mathrm{t}_{(282)}=-2.25 ; p=.03\right]$. Bu analiz sonucuna göre geniş aile içerisinde yaşayan kadınların çekirdek aile içerisinde yaşayanlara göre onaylanmaya daha çok ihtiyaç duydukları söylenebilir.

\section{SONUÇ, TARTIŞMA ve ÖNERİLER}

$\mathrm{Bu}$ çalışmada 35-60 yaş aralığındaki kadınlar üzerinde sosyal onay ihtiyacı, kendini sansürleme isteği ve depresyon değişkenleri arasındaki ilişkilerin incelenmesi amaçlanmıştır. Elde edilen bulgular bu çalışma değişkenlerinin birbirleriyle manidar bir şekilde ilişki içerisinde olduklarını göstermektedir. Bu bölümde öncelikle çalışma değişkenleri arasındaki ilişkilere ardından bu değişkenlerin bazı bağımsız değişkenler (eğitim durumu, çalışma durumu, medeni durum, sosyal güvence, aile tipi) ile farklılaşma durumlarına dair tartısmaya yer verilmiştir.

Yapılan analizler sonucunda ilk olarak kadınların sosyal onay ihtiyacı ile kendini sansürleme isteği arasında orta derecede pozitif yönde manidar bir ilişkinin olduğu görülmüştür. Yani 
kadınların sosyal onay almaya yönelik ihtiyaçları arttıkça kendini sansürleme özellikleri de manidar bir şekilde artış göstermektedir. Bu bulgu sosyal onay ihtiyacındaki artışın; kadınların kendilerini oldukları gibi ifade etmeleri yerine, çevredekilerin onayını alabilecekleri şekilde esas düşüncelerini kırparak etkileşim kurmaları açısından, kendini sansürleme isteği üzerinde anlamlı etkide bulunmasıyla açılanabilir. Bu bulgu bir döngü olarak düşünüldüğünde, kendini sansürleyen kadınların sosyal açıdan onaylanmaya daha çok ihtiyaç duydukları yönünde yorumlanabilir. Bu noktada sosyal onay ihtiyacının onaylanmamaktan kaçınmak adına sessiz kalmayı tercih etme noktasında (Coşkun, Durak ve Elgin, 2012) kendini sansürleme isteği ile kesiştiği açıkça ortadadır. Aynı zamanda Ekşi, Bikeç ve Ümmet (2017)'in çalışmasında onay almanın kendini sansürleme üzerinde önemli bir yordayıcı olduğu bulunmuştur. Dolayısıyla bu bulgu ilgili literatürden elde edilmiş bilgilerle uyumlu olarak değerlendirilmektedir. Diğer yandan Coşkun (2009) gerçekleştirdiği çalışmada kendini sansürleme ile etkileşim kaygısı arasında ve Hayes ve arkadaşları (2005) sosyal kaygı ile kendini sansürleme arasında pozitif yönde manidar ilişkiler saptamıştır. Buradan hareketle Erözkan (2005) ve Ceylan (2011)'ın onay ihtiyacının sosyal kaygının önemli yordayıcılarından biri olduğu bulgusu ile Lohr ve Rea (1981)'nın topluluk karşısında konuşma kaygısı ile akılcı olmayan inançlar arasındaki ilişkiyi inceledikleri çalışmada 10 akılcı olmayan inançtan yalnızca onaylanma ihtiyacının pozitif yönde ilişki gösterdiği bulgusu çalışmadan elde edilen sonuçları destekler niteliktedir.

Kadınların sosyal onay ihtiyacı ile depresyon düzeyi arasındaki ilişkiye dair analiz sonuçları bu iki değişken arasında orta derecede pozitif yönde manidar bir ilişkinin olduğunu göstermektedir. Onaylanma ihtiyacı başkaları tarafından hoşlanılma ve reddedilmekten kaçınma arayışını yansıtan ögeleri içermektedir (Boyce ve Parker, 1989). Beraberinde Türk kültürüne bakıldığında, sosyal kabullerin kişiler üzerinde güçlü etkisinin varlığı bilenen bir durum olarak karşımıza çıkmaktadır (Ekşi, Bikeç ve Ümmet, 2017). Bu yönüyle çalışmadan edinilen bu bulgu kişinin kendi değerinin (Eberhard, Matthes ve Ulrich, 2015) veya mutluluğunun başkalarının onayına bağlı olduğu inancı ile açıklanabilir (Dobson ve Dozois, 2008). Dolayısıyla onaylanma ihtiyacının, kişilerde yüksek beklentileri oluşturarak depresyona neden olduğu söylenebilir. Bebek (2012) Onay Bağımlılı̆̆ Ölçeği'nin geçerlik çalışmaları sırasında Beck Depresyon Ölçeği'ni kullanmış ve iki ölçek arasındaki ölçüt bağıntılı geçerlik puanının yüksek olduğunu bulmuştur. Diğer yandan akılcı olmayan inançlarla depresyon arasındaki ilişkinin incelendiği çeşitli çalışmalarda da onaylanma ihtiyacı ile depresyon arasında ilişkinin olduğu görülmüştür (Mclennan, 1987; Stanciu, 2014; Balkıs ve Duru, 2018). Dolayısıyla çalışma bulgusunun literatür ile uyumlu olduğu görülmektedir.

Kadınların kendini sansürleme isteği ile depresyon düzeyi arasındaki ilişkiye dair analiz sonuçları, bu iki değişken arasında düşük düzeyde pozitif yönde manidar bir ilişkinin olduğunu göstermektedir. Bu bulgu duyguların ve düşüncelerin açıkça ifade edilmemesi ile kişinin olduğu gibi davranmaktan bilinçli olarak geri durması gibi kendini sansürlemeye yönelik durumların, kişinin kendisini huzursuz, tedirgin, mutsuz hissetmesi ile sosyal anlamda kendini güçsüz bulması neticesinde ruh halinde olumsuz etkilere yol açabileceği gibi depresyonu tetikleyebileceği yönünde yorumlanabilir. Diğer bir ifadeyle bu bulgu, devamlı olarak gerçek görüşleri paylaşmaktan geri durulmasının, kişide depresyona yönelik eğilimi arttırabileceği şeklinde açıklanabilir. Elde edilen bu bulgu literatürdeki çeşitli çalışmalar tarafindan desteklenmektedir (Jack ve Dill, 1992; Duarte ve Thompson, 1999; Ali, Oatley ve 
Toner, 2002; Ali ve Toner, 2001). Buradan hareketle açı ve kabul edici bir şekilde kurulan iletişimin ruh sağlığı üzerindeki önemi bir kez daha karşımıza çıkmaktadır.

Araştırma değişkenlerinin bağımsız değişkenlere göre farklılaşmalarına dair elde edilen bulgulara bakıldığında; kadınlardaki kendini sansürleme isteğinin eğitim düzeyine göre manidar bir şekilde farklılık gösterdiği ve bu farklılaşmanın üniversite mezunlarının lehine olup, ilkokul mezunu kadınlardaki kendini sansürleme isteğinin daha yüksek olduğu sonucuna ulaşılmıştır. Bu bulgu eğitim düzeyindeki yükselmenin, kadınların kendi düşüncelerini tartışmaya açık bir şekilde özgürce ifade edebilmeleri noktasında önemli bir belirleyici olduğu yönünde açıklanabilir. Öte yandan depresyon ve sosyal onay ihtiyacı değişkenlerinin eğitim düzeyine göre farklılaşmadı̆̆ı saptanmıştır. Cengiz-Özyurt ve Deveci (2010); Önen, Kaptanoğlu ve Seber (1995) ve Hall (1990)'ın kadınlar üzerinde gerçekleştirmiş oldukları çalışmalara bakıldığında ise eğitim düzeyinin artmasıyla birlikte depresyon belirtilerinin azaldığı görülmektedir. Bir diğer araştırmada ise eğitim düzeyindeki artışın depresyona yönelik risk faktörlerinden biri olduğu ortaya konmuştur (Lök ve Bademli, 2017). Ayrıca Değirmenci (2019)'nin çalışmasında eğitim düzeyi arttıkça sosyal onay ihtiyacında manidar bir azalmanın olduğu görülmüştür. Bu yönleriyle çalışmanın bu iki bulgusunun literatürle çeliştiği görülmektedir.

Kadınların çalışma durumları ele alındığında herhangi bir işte çalışanlara kıyasla çalışmayan kadınlarda kendini sansürleme isteği ve depresyon düzeyi manidar bir şekilde daha yüksek bulunmuştur. Depresyon düzeyi açısından Bilgin (1990), Etiler (2015) ve Kaya (2019)'nın kadınlarla gerçekleştirdikleri çalışmalarda benzer sonuçların elde edildiği görülmektedir. Bu bulgular maddî anlamda dışa bağımlı olmamakla birlikte iş hayatında kendilerini daha çok ifade edebilme fırsatı yakalayan kadınların, kendilerine özgü tutumları sergileme noktasında daha rahat hissedebilmeleri neticesinde depresif eğilimden uzak bir ruh hali içerisinde olabildikleri yönünde açıklanabilir. Bu noktada belirtmek gerekir ki, kadınların çalışmayı seçip seçmedikleri ve kendilerine bu doğrultuda yönlendirmelerin yapılıp yapılmadığının irdelenmesi depresyon belirtilerinin değerlendirilmesinde oldukça önemli yer tutmaktadır (Paykel, 1991). Çalışma durumuna ilişkin son olarak, sosyal onay ihtiyacının da 'çalışan' ve 'çalışmayan' grupları arasında farklılaşması beklenmiş ancak gruplar arası manidar bir farklılık saptanmamıştır. Çalışmanın bu bulgusunun Değirmenci (2019)'nin sosyal onay ihtiyacı kapsamında çalışmayan grubun diğer gruplara kıyasla daha yüksek sosyal onaya ihtiyaç duydukları bulgusu ile çeliştiği görülmektedir. Ayrıca bu bulguların neticesinde kendini sansürleme isteği ve depresyon değişkenlerinin sosyal güvenceye bağlı olarak farklılaşması beklenmiş fakat sosyal güvenceye bağlı olarak çalışma değişkenlerinin tümü üzerinde manidar bir farklılaşmanın olmadığı görülmüştür.

Kadınlardaki kendini sansürleme isteğinin medeni durum değişkenine göre manidar bir şekilde farklılaştığı ve bu durumun bekâr-eşi vefat etmiş ve boşanmış-eşi vefat etmiş olan kadınlar arasındaki farklılaşmadan kaynaklandığı görülmüştür. Bu sonuca göre eşi vefat eden kadınlar, bekâr ve boşanmış kadınlara kıyasla kendilerine ait gerçek düşünceleri içinde bulundukları topluluk ile manidar bir şekilde daha az paylaşmaktadır. Kınacıgil (2020) çalışmasında, boşanmış veya eşi vefat etmiş kadınların etiketlenme ve dışlanma sorunlarıyla oldukça sık karşılaştıkları sonucuna ulaşmıştır. Buradan hareketle kadınların toplum içerisinde 'dul' olarak etiketlenmeleri ve çeşitli dışlanmalara maruz kalmaları sonucu kendilerini sansürlemeye yöneldikleri söylenebilir. Diğer yandan kadınlarda sosyal onay 
ihtiyacı ve depresyon değişkenlerinin medeni duruma bağlı olarak manidar bir şekilde farklılaşmadiğı görülmüştür.

Son olarak, kadınlarda sosyal onay ihtiyacının aile tipine göre manidar bir farklılık gösterdiği bulunmuş ve bu farklılaşmanın çekirdek aile içerisinde yaşayan kadınların lehine olduğu görülmüştür. Yani geniş aile içerisinde yaşayan kadınlar çekirdek aile içerisinde yaşayanlara kıyasla sosyal açıdan onay almaya daha çok ihtiyaç duymaktadır. Literatüre bakıldığında geniş ailede yetişenlerin çekirdek ailede yetişenlere göre kendilerinden yaşça üstün kişilere daha fazla itaat ettikleri ve onların onayı ile iş yapmaları gerektiğini düşündükleri sonucuna ulaşılmıştır (Pehlivan, 2017). Dolayısıyla çalışmanın bu bulgusu, geniş ailelerde yaşayan kadınların herhangi bir olay karşısında diğer aile üyelerinin onayına ihtiyaç duymaları ile bu durumu yaşamlarının önemli bir kısmına yansıtmış olabilecekleri yönünde açıklanabilir.

Sonuçta bu araştırmadan; kadınların sosyal onay ihtiyaçları, kendini sansürleme istekleri ile depresyon düzeylerinin birbirleriyle ilişkili olduğu sonucu elde edilmiştir. Kadınların sosyal yaşam içerisindeki yerlerini ve psikolojik ihtiyaçlarını göz önüne aldığımızda yapılacak psikolojik yardım çalışmalarında özellikle öz güven, iletişim becerilerinin desteklenmesi, kendilik algısı gibi konuların hem geniş aile yapısı içinde olan hem de eşinden ayrılmış ya da eşini kaybetmiş kadınlarda öncelikli olarak üzerinde durulması önerilebilir. Bu yolla daha etkili ve daha hızlı yardım söz konusu olabilir. Ayrıca eğitim durumlarına göre farklılaşan bulgular göz önüne alındığında özellikle yerel kuruluşlar, sivil toplum örgütleri ve eğitim kuruluşları tarafından kadınlara yönelik bilgilendirici seminerler veya destek gruplarında da depresyonla başa çıkma, kendilik algısı ve özgüven konularının ön planda olduğu çalışmalara ağırlık verilmesi önerilebilir. Bu yolla bireysel gelişim daha etkili bir şekilde desteklenebilir.

$\mathrm{Bu}$ çalışmanın çeşitli sınırlılıkları bulunmaktadır. Çalışma grubunu yalnızca İstanbul'da yaşayan kadınlar oluşturmuştur. Katılımcıların yaşları 35-60 yaş aralığı ile sınırlandırılmıştır. Katılımcıların tıbbi rahatsızlıklarının olup olmadığı ya da fiziksel engelli olup olmadıkları araştırma kapsamına alınmamıştır. Ayrıca okula gitmeyen kadın sayısı 15 ile sınırlı kalmıştır. Gelecekteki araştırmacılara, bu çalışma değişkenlerine toplumsal cinsiyet algısı eklenerek, farklı illerde yaşayan kişiler üzerinde uygulanması ve toplumsal yapı açısından karşılaştırmaların yapılması önerilebilir. Yine bu çalışma değişkenleriyle farklı yaş ve cinsiyet grupları üzerinde çalışmalar gerçekleştirilebilir.

\section{KAYNAKÇA}

Ali, A., Oatley, K., and Toner, B. B. (2002). Life stress, self-silencing, and domains of meaning in unipolar depression: An investigation of an outpatient sample of women. Journal of Social and Clinical Psychology, 21, 669-685.

Ali, A., ve Toner, B. B. (2001). Symptoms of depression among Caribbean women and Caribbean-Canadian women: An investigation of self-silencing and domains of meaning. Psychology of Women Quarterly, 25, 175-180. 
Ambler, B. ve Elkins, M. (1986). Defining and confirming the relationship between irrational beliefs and communication apprehension: An extension. Paper presented at the annual meeting of the Speech Communication Association, Chicago, IL. 20 Mays 2019 tarihinde https://eric.ed.gov/?id=ED278081 adresinden erişildi.

Balkıs, M. ve Duru, E. (2018). The protective role of rational veliefs on the relationship between irrational beliefs, emotional states of stress, depression and anxiety. Journal of RationalEmotive \& Cognitive-Behavior Therapy, 37, 96-112.

Baltacı, A. (2018). Nitel araştırmalarda örnekleme yöntemleri ve örnek hacmi sorunsalı üzerine kavramsal bir inceleme. Bitlis Eren Üniversitesi Sosyal Bilimler Enstitüsü, 7(1), 231-274.

Barreto, M. ve Ellemers, N. (2000). You can't always do what you want: Social identity and selfpresentational determinants of the choice to work for a low-status group. Personality and Social Psychology Bulletin, 26(8), 891-906.

Bilgin, M. (1990). Çalışan ve çalışmayan kadınlara ilişkin bazı değişkenlerin depresyon düzeylerine etkisi. Yayımlanmamış yüksek lisans tezi, Hacettepe Üniversitesi, Ankara.

Bebek, H. (2012). Onay Bağımlılığı Ölçeği'nin geçerlilik ve güvenilirlik çalışması. NP Akademi, 1(2), 30-35.

Barnow, S., Linden, M., Lucht, M. ve Freyberger, H.-J. (2002). The importance of psychosocial factors, gender, and severity of depression in distinguishing between adjustment and depressive disorders. Journal of Affective Disorders, 72(1), 71-78.

Boyce, P. ve Parker, G. (1989). Development of a scale to measure interpersonal sensitivity. Australian and New Zealand Journal of Psychiatry, 23(3), 341-51.

Buckhout, R. (1965). Need for social approval and attitude change. The Journal of Psychology, 60(1), 123-128.

Canll, D. ve Karaşar, B. (2021). Predictors of major depressive disorder: The Need for social approval and self-esteem. Alpha Psychiatry, 22(1), 38-42.

Cengiz-Özyurt, B. ve Deveci, A. (2010). Manisa'da kırsal bir bölgedeki 15-49 yaş evli kadınlarda depresif belirti yaygınlığı ve aile içi şiddetle ilişkisi. Türk Psikiyatri Dergisi, $20,1-7$.

Ceylan, H. (2011). Üniversite öğrencilerinin sosyal kaygı düzeylerinin yordanması. Yayımlanmamış yüksek lisans tezi, Ege Üniversitesi, İzmir.

Chan, M. (2018). Reluctance to talk about politics in face-to-face and Facebook settings: Examining the impact of fear of isolation, willingness to self-censor, and peer network characteristics. Mass Communication and Society, 21(1), 1-23.

Coşkun, H. (2009). Etkileşim Kaygısı Ölçeği: Geçerlik ve güvenirlik çalışması. Türk Psikoloji Yazılarl, 12(23), 41-49.

Coşkun, H., Durak, M. ve Elgin, V. M. (2012). Kendini Sansürleme İsteği Ölçeği: Geçerlilik ve güvenilirlik çalışması. New Symposium Journal, 50(2), 83-89.

Crowne, D. P. ve Strickland, B. R. (1961). The conditioning of verbal behavior as a function of the need for social approval. Journal of Abnormal and Social Psychology, 63(2), 395-401. 
Danilchenko, T.V. (2018). Gender differences of experiencing of subjective social well-being. European. Journal of Psychology and Educational Research, 1(1), 1-10.

Das, S. ve Kramer, A. (2013). Self-censorship on Facebook. AAAI Conference on Weblogs and Social Media, $\quad 120-127 . \quad 20 \quad$ Mayıs $2019 \quad$ tarihinde https://www.aaai.org/ocs/index.php/ICWSM/ICWSM13/paper/view/6093 adresinden erişildi.

Değirmenci, E. (2019). Çekirdek veya geniş ailede yetişen bireylerde sosyal onay ihtiyacı ile benliğin ayrımlaşması arasındaki ilişkinin incelenmesi. Yayımlanmamış yüksek lisans tezi, İstanbul Ticaret Üniversitesi, İstanbul.

Dinç-Yurtal, F. (1999). Üniversite öğrencilerinin akılcı olmayan inançlarının bazı değişkenlere göre incelenmesi. Yayımlanmamış doktora tezi, Gazi Üniversitesi, Ankara.

Dobson, K. S. ve Dozois, D. (Eds). (2008). Risk Factors in depression. San Diego, CA, US: Elsevier Academic Press. 1 Ocak 2019 tarihinde https://books.google.com.tr/books?hl=tr\&lr=\&id=yTrbVd6av9wC\&oi=fnd\&pg=PP1\&d $\mathrm{q}=$ Dobson,+ K. + S. + and + Dozois,, D..$+($ Eds. $) .+(2008) .+$ Risk + Factors + in + depression\&ots $=Y$ 65xLtzDPp\&sig=ISmYL-

zR0CnVa2oyCITezmcdczQ\&redir esc=y\#v=onepage\&q=Dobson $\% 2 C \% 20 \mathrm{~K} . \% 20 \mathrm{~S} . \% 20$ and\%20Dozois\%2C\%20D.\%20(Eds.).\%20(2008).\%20Risk\%20Factors\%20in\%20depressi on\&f=false adresinden erişildi.

Duarte, L. M. ve Thompson, J. M. (1999). Sex differences in self-silencing. Psychological Reports, $85,145-161$.

Eberhard, V., Matthes, S. ve Ulrich, J. G. (2015). The need for social approval and the choice of gender-typed occupations. Gender Segregation in Vocational Education, 31, 205-235.

Ekşi, H., Bikeç, S. M. ve Ümmet, D. (2017). Öğretmen adaylarında kendini sansürleme, psikolojik kırılganlık ve koşullu öz değer. Küreselleşen Dünyada Eğitim, 440-450.

Erözkan, A. (2005). Üniversite öğrencilerinin kişilerarası duyarlılık ve depresyon düzeylerinin bazı değişkenlere göre incelenmesi. Muğla Üniversitesi Sosyal Bilimler Enstitüsü Dergisi, 14, 129-155.

Eryılmaz, N., Pekuslu, S. ve Kayac1, M. (2007). Engelli çocuğa sahip ebeveynlerin depresyon düzeyi ve etkileyen faktörlerin belirlenmesi. Atatürk Üniversitesi Hemşirelik Yüksekokulu Dergisi, 10(1), 41-48.

Gino, F., Sezer, O. ve Huang, L. (2020). To be or not to be your authentic self? Catering to others' preferences hinders performance. Organizational Behavior and Human Decision Processes, 158(12), 83-100.

Grant, T. M., Jack, D. C., Fitzpatrick, A. L. ve Ernst, C. C. (2009). Carrying the burdens of poverty, parenting, and addiction: Depression symptoms and self-silencing among ethnically diverse women. Community Mental Health Journal, 47(1), 90-98.

Hall, L. A. (1990). Prevalence and correlates of depressive symptoms in mothers of young children. Public Health Nursing, 7(2), 71-79. 
Hayes, A. F., Glynn, C. J. ve Shanahan, J. (2005). Willingness to Self-Censor: A construct and measurement tool for public opinion research. International Journal of Public Opinion Reseach, 17(3), 298-323.

Hayes, A. F., Uldall, B. R. ve Glynn, C. J. (2010). Validating the Willingness to Self-Censor Scale II: Inhibition of opinion expression in a conversational setting. Communication Methods and Measures, 4(3), 256-272.

Hisli, N. (1989). Beck Depresyon Envanterinin üniversite öğrencileri için geçerliği, güvenirliği. Psikoloji dergisi, 7(23), 3-13.

Hurst, R. J. (2010). Testing a relational-cultural model of sexism: Perceived sexist discrimination, ambivalent sexism, self-silencing, and psychological distress in collage women. Yayımlanmamış doktora tezi, University of Oklohoma, Norman.

Jack, D. C. ve Dill, D. (1992). The silencing the self-scale: Schemas of intimacy associated with depression in women. Psychology of Women Quarterly, 16, 97-106.

Jones, S. C. ve Tager, R. (1972). Exposure to others, need for social approval, and reactions to agreement and disagreement from others. The Journal of Social Psychology, 86(1), 111120.

Karaşar, B. ve Öğülmüş, S. (2016). Sosyal Onay İhtiyacı Ölçeği: Geçerlik ve güvenirlik analizi. Ege Ĕ̆itim Dergisi, 1(17), 84-104.

Kaya, R. (2019). Çalışan ve çalışmayan kadınlarda depresyon belirtilerinin yaşam kalitesine, uyku kalitesine ve gece yeme bozukluğuna etkileri. Yayımlanmamış yüksek lisans tezi, Beykent Üniversitesi, İstanbul.

Kayahan, B., Altıntoprak, E., Karabilgin, S. ve Öztürk, Ö. (2003). On beş-kırk dokuz yaşları arasındaki kadınlarda depresyon prevalansı ve depresyon şiddeti ile risk faktörleri arasındaki ilişki. Anadolu Psikiyatri Dergisi, 4, 208-219.

Kendler, K. S., Thornton, L. M. ve Prescott, C. A. (2001). Gender differences in the rates of exposure to stressful life events and sensitivity to their depressogenic effects. Am J Psychiatry, 158(4), 587-93.

Kınacıgil, G. (2020). Ataerkillik ve toplumsal baskl: Gaziantep'te dul kadın olmak. Yayımlanmamış yüksek lisans tezi, Gaziantep Üniversitesi, Gaziantep.

Komut, S. (2011). Türkiye' de kadın, cinsellik ve kürtaj. Sosyal ve Beşeri Bilimler Dergisi, 3(1), 8795.

Leary, M. R. (2007). Motivational and emotional aspects of the self. The Annual Review of Psychology, 58, 317-344.

Leary, M. ve Kowalski, R. (1990). Impression management: A literature review and twocomponent model. Psychological Bulletin, 107(1), 34-47.

Leite, W. L. ve Beretvas, S. N. (2005). Validation of scores on the Marlowe-Crowne social desirability scale and the balanced inventory of desirable responding. Educational and Psychological Measurement, 65(1), 140-154. 
Lohr, J. M. ve Rea, R. G. (1981). A disconfirmation of the relationship between fear of public speaking and irrational beliefs. Psychological Reports, 48, 191-194.

Lök, N. ve Bademli, K. (2017). Yetişkin bireylerde fiziksel aktivite ve depresyon arasındaki ilişkinin belirlenmesi. Mustafa Kemal Üniversitesi Sosyal Bilimler Enstitüsü Dergisi, 14(40), 101-110.

McCollum, D. L. (2009). What are the social values of college students?: A social goals approach. Journal of College and Character, 6(6), 1-21.

McLennan, J. P. (1987). Irrational beliefs in relation to self-esteem and depression. Clinical Psychology, 45(6), 1190-1191.

Okyay, P., Atasoylu, G., Önde, M., Dereboy, Ç. ve Beşer, E. (2011). Kadınlarda yaşam kalitesi anksiyete ve depresyon belirtilerinin varlığında nasıl etkileniyor? Kesitsel bir alan çalışması. Türk Psikiyatri Dergisi, 23(3), 178-88.

Önen, F. R., Kaptanoğlu, C. ve Seber, G. (1995). Kadınlarda depresyonun yaygınlığı ve risk faktörlerle ilişkisi. Kriz Dergisi, 3(1-2), 88-103.

Paykel, E. S. (1991). Depression in women. British Journal of Psychiatry, 158(10), 22-29.

Pehlivan, O. (2017). Aile tanımı ve ilişkilerinin toplumsal olarak inşası. Yayımlanmamış doktora tezi, Hacettepe Üniversitesi, Ankara.

Quinlan, D. M., Pilkonis, P. A. ve Shea, T. (1995). Impact of perfectionism and need for approval on the brief treatment of depression: The national institute of mental health treatment depression collaborative research program revisited. Journal of Consulting and Clinical Psychology, 63(1), 125-132.

Stanciu, M. M. (2014). The connection between gender, academic performance, irrational beliefs, depression and anxiety among teenagers and younger adults. Romanian Journal of Cognitive Behavioral Therapy and Hypnosis, 1(2), 1-13.

Şahan, B. ve Akbaş, T. (2018). Kültürel olarak farklı ailelerle psikolojik danışma ve Türk aile yapısında kültürün rolü. Buca Ĕ̆itim Fakültesi Dergisi, 46, 217-239.

Twenge, J. M. ve Im, C. (2007). Changes in the need for social approval 1958-2001. Journal of Research in Personality, 41(1), 171-189.

Yıldırım, A. ve Şimşek, H. (2018). Sosyal bilimlerde nitel araştırma yöntemleri. Ankara: Seçkin Yayıncilik. 